\title{
Asimetri informasi dan Budgetary Slack (Studi pada Pemerintah Kabupaten Dompu)
}

\author{
Lukman Effendy
}

\begin{abstract}
This study aims to examine the effect of informationa asymetry towards budgetary slack at Dompu District Local Goverment. The population is all of structural officials at SKPD of Dompu Disctrict Local Goverment. The amount of sample is is 74 respondent, which is resulted by Tabachnick and Fidel (2007) approach. The data were obtained by spreading 74 questionnaires to 74 respondents. The data were analyzed using Partial Least Square Ver. 3.00, to know the influence Information Asymetry to Budgetary Slack. The results of this study indicate that information asymetry dont have a significant effect on Budgetary Slack.

Keyword: Information Asymetry, Budgetary Slack
\end{abstract}

\section{LATAR BELAKANG}

Setiap organisasi, tidak terkecuali organisasi pemerintahan tentu memiliki tujuan organisasi yang telah ditetapkan. Keselaran tujuan antar komponen dalam organisasi adalah suatu keniscayaan. Organisasi sulit berkembang tanpa adanya keselarasan tujuan dalam tubuh organisasi. Tugas pengelola/manajemenlah untuk menyelaraskan tujuan tiap komponen dengan tujuan organisasi.

Pengendalian manajemen yang baik berguna untuk memastikan adanya goal congruence organisasi yang optimal. Segenap komponen organisasi diarahkan untuk mengambil tindakan yang sesuai dengan kepentingan pribadi mereka sendiri yang sekaligus juga merupakan kepentingan organisasi.

Organisasi dapat menggunakan Anggaran untuk dapat mengendalikan semua komponen organisasi. Anthony dan Govindarajan (2007) mendefinisikan anggaran sebagai hal penting dalam perencanaan dan pengendalian jangka pendek. Anggaran adalah bentuk komitmen organisasi dalam bentuk alokasi sumber daya, untuk dijadikan sebagai acuan operasional organisasi.

Dalam organisasi pemerintahan, anggaran dapat dijadikan sebagai alat untuk mencapai menciptakan tujuan sosial ekonomi yang diinginkan, dan meningkatkan kesejahteraan dalam kehidupan masyarakat. Anggaran adalah 
Lukman Effendy: Asimetri Informasi dan Budgetary Slack...

merupakan suatu bentuk komitmen pemerintah terhadap rakyatnya dan anggaran juga merupakan manifestasi pertanggungjawaban pemerintah terhadap rakyatnya.

Undang-undang Nomor 32 Tahun 2004 yang diubah dengan Undangundang Nomor 23 Tahun 2014 yang mengatur tentang pada pemerintah daerah telah merubah sistem operasional prosedur penyusunan Anggaran Pendapatan dan Belanja Daerah. Sistem operasional prosedur yang baru menuntut adanya peran aktif dan keterlibatan semua pihak dalam penyusunan APBD. Anggaran disusun mulai dari tingkatan SKPD hingga kepada kepala daerah.

Anggaran Pendapatan dan Belanja Daerah yang semula disusun topdown menjadi bottom-up. APBD Perubahan ini merupakan suatu konsep sistem penganggaran dengan berbasis New Public Management (NPM) yang diadopsi oleh pemerintah. Manajemen sektor publik telah menjadi suatu manajemen yang lebih fleksibel dan menyesuaikan dengan lingkungannya.

Penyusunan anggaran bottom-up diharapkan dapat memberikan pencapaian anggaran yang tinggi. Keakuratan anggan menjadi lebih tinggi, walaupun kemungkinan untuk kesenjangan anggaran tetap ada yang disebabkan perbedaan informasi (asimetri informasi) antara manajemen puncak dengan manajemen yang ada di bawahnya.

Pemerintah Kabupaten Dompu sebagai organisasi pemerintahan tentu menyusun anggarannya dengan sistem bottom-up. Anggaran disusun dengan menyesuaikan dengan kebutuhan masyarakat, dan disesuaikan dengan Rencana Kerja Pemerintah Daerah (RKPD). Berikut ini adalah Pendapatan dan Belanja Pemerintah Kabupaten Dompu:

Tabel 1. Komposisi Pendapatan dan Belanja Kabupaten Dompu Tahun 2014

\begin{tabular}{|l|c|c|c|}
\hline \multirow{2}{*}{\multicolumn{1}{c|}{ Uraian }} & \multicolumn{3}{|c|}{ TAHUN 2014} \\
\cline { 2 - 4 } & Anggaran & Realisasi & $\%$ \\
\hline Pendapatan Asli Daerah & 71.373 .940 .344 & 75.370 .940 .344 & 105 \\
\hline Pendapatan Transfer & 714.014 .076 .360 & 713.417 .226 .120 & 99 \\
\hline Lain-lainya yang sah & 10.918 .827 .500 & 11.794 .299 .900 & 108 \\
\hline Belanja Operasi & 649.497 .724 .236 & 606.209 .803 .509 & 93 \\
\hline Belanja Modal & 128.296 .026 .565 & 120.607 .395 .775 & 94 \\
\hline Belanja Tak terduga & 1.260 .756 .739 & 398.943 .000 & 31 \\
\hline
\end{tabular}


Pada Tabel 1 dapat dilihat bahwa realisasi pendapatan lebih tinggi dibandingkan dengan anggaran (understated). Demikian sebaliknya, bahwa realisasi belanja lebih rendah dibandingkan dengan anggaran (overstated). Hal tersebut bisa disebabkan karena adanya asimetri informasi.

Asimetri informasi yang memiliki pengaruh terhadap selisih anggaran telah diteliti sebelumnya oleh Gamal (2001) dan Falikhatun (2007), yang menyatakan bahwa asimetri informasi berpengaruh negatif signifikan terhadap selisih anggaran. Dapat disimpulkan bahwa asimetri informasi dapat mengurangi terjadinya selisih anggaran.

Penelitian ini dilakukan untuk menguji kembali bukti empiris tersebut, dengan lokasi penelitian yang berbeda, yaitu di Pemerintah Kabupaten Dompu.

\section{Rumusan Masalah}

Berdasarkan uraian pada latar belakang, maka dirumuskan masalah penelitian sebagai berikut: "apakah asimetri informasi mempengaruhi selisih anggaran?"

\section{Tujuan Penelitian}

Berdasarkan rumusan masalah, penelitian ini bertujuan untuk menganalisis pengaruh asimetri informasi terhadap selisih anggaran.

\section{Teori Keagenan}

\section{TINJAUAN PUSTAKA}

Menurut Jensen dan Meckling (1976), teori keagenan adalah konsep yang menjelaskan hubungan kontraktual antara prinsipal dan agen, yaitu antara dua atau lebih individu, kelompok atau organisasi. Pihak prinsipal adalah pihak yang mengambil keputusan dan memberikan mandat kepada pihak lain (agen), untuk melakukan semua kegiatan atas nama prinsipal. Jensen dan Meckling (1976) menyatakan permasalahan tersebut, antara lain: 1) moral hazard adalah permasalahan yang muncul karena agen tidak melaksanakan hal-hal yang telah disepakati bersama sesuai kontrak kerja; dan 2) adverse selection adalah prinsipal tidak mengetahui bahwa keputusan yang diambil oleh agen merupakan keputusan yang sesuai dengan informasi yang diterima oleh prinsipal atau terjadi kelalaian dalam bertugas.

Praktik senjangan anggaran mengandung pengertian dari teori keagenan, yaitu adanya konflik kepentingan antara agen (manajemen) dengan principal. Teori keagenan yang dijelaskan oleh Anthony dan Govindarajan (2007) merupakan suatu fenomena yang terjadi apabila atasan 
Lukman Effendy: Asimetri Informasi dan Budgetary Slack...

mendelegasikan wewenang kepada bawahan untuk melakukan suatu otoritas atau tugas dalam membuat keputusan.

\section{Budgetary Slack}

Senjangan anggaran (budget slack) adalah perbedaan antara jumlah anggaran dan jumlah estimasi terbaik (Anthony dan Govindarajan, 2007). Senjangan anggaran adalah perbedaan antara anggaran yang dinyatakan dan estimasi anggaran terbaik yang secara jujur dapat diprediksi serta dibuat oleh penyusun anggaran dalam penganggaran. Variabel ini diukur dengan instrumen Dunk (1993).

Masih Menurut Dunk (1993) manajer lebih cendrung menyusun anggaran yang lebih mudah untuk dicapai. Prilaku manajer melakukan senjangan anggaran dipengaruhi oleh kebijakan direktur yang menilai kinerja manajer berdasarkan pencapaian sasaran anggaran. Senjangan anggaran biasanya dilakukan dengan meninggikan biaya atau menurunkan pendapatan dari yang seharusnya, supaya anggaran mudah dicapai.

Pada saat seorang bawahan mengetahui bahwa kinerjanya akan dinilai berdasarkan tingkat pencapaian atau realisasi dari anggaran yang dibuat maka dalam proses penyusunan anggaran akan ada kecenderungan membuat target yang mudah untuk dicapai sehingga mereka berkesempatan memperoleh reward atau penghargaan dari organisasi. Hal di atas sesuai dengan penjelasan sebelumnya bahwa manajer memiliki kecenderungan untuk menetapkan tujuan yang terlalu tinggi sesuai dengan tujuan pribadi atau terlalu rendah untuk memudahkan pencapaian dan mengurangi resiko. (Fitriasuri, 2005).

Senjangan anggaran terjadi karena disebabkan oleh empat kondisi menurut Eisenhardt dan Stevens dalam Fitri (2004). Pertama, terdapat informasi asimetri antara manajer (bawahan) dengan atasan mereka. Kedua, kinerja manajer tidak pasti. Jika terdapat kepastian dalam kinerja, maka atasan dapat menduga usaha manajer melalui output mereka sehingga senjangan anggaran sulit untuk dilakukan. Ketiga, manajer mempunyai kepentingan pribadi. Keempat, adanya konflik tujuan antara manajer dengan atasan mereka. Selanjutnya Dunk (1993) menyatakan pentingnya peranan manajer dalam partisipasinya terhadap proses penganggaran. Artinya, manajer mampu mempengaruhi hasil dan proses penganggaran untuk dapat menciptakan budgetary slack.

\section{Asimetri Informasi}

Rani (2015) menyatakan bahwa penentuan anggaran yang tepat memang tidak mudah dan akan menjadi masalah apabila bawahan 
mempunyai informasi yang lebih baik dibandingkan informasi yang dipunyai atasan. Perbedaan informasi yang dimiliki antara atasan dan bawahan inilah yang dinamakan informasi asimetri. Adanya informasi asimetri merupakan salah satu faktor yang menimbulkan perilaku negatif dalam hal ini adalah senjangan anggaran (budgetary slack).

Suartana (2010) menjelaskan bahwa konsep informasi asimetris yaitu atasan anggaran mungkin mempunyai pengetahuan dan wawasan yang lebih daripada bawahan, ataupun sebaliknya. Bila kemungkinan yang pertama terjadi, akan muncul tuntutan atau motivasi yang lebih besar dari atasan kepada bawahan mengenai pencapaian target anggaran yang menurut bawahan terlalu tinggi. Namun bila kemungkinan yang kedua terjadi, bawahan akan menyatakan target lebih rendah daripada yang dimungkinkan untuk dicapai.

Keadaan dimana salah satu pihak mempunyai pengetahuan dan informasi lebih daripada yang lainnya terhadap sesuatu hal disebut asimetri informasi". Baiman dan Evans dalam Erawati (2006) asimetri informasi timbul jika bawahan memiliki informasi yang relevan untuk proses pembuatan keputusan sehubungan dengan penganggaran sedangkan atasan tidak. Asimetri informasi merupakan perbedaan informasi relevan yang digunakan dalam pengambilan keputusan antara manajer tingkat atas dengan manajer tingkat bawah.

Young (1985) menyatakan bahwa keberadaan asimetri informasi dapat menyebabkan bawahan untuk melebih-lebihkan kebutuhan sumber daya mereka atau mengecilkan kemampuan kerja mereka. Sehingga, interaksi antara anggaran partisipatif dengan asimetri informasi dapat menyebabkan terjadinya budgetary slack. Secara teoritis, asimetri informasi dapat dikurangi melalui monitoring dan desain sistem informasi yang lebih baik. Contohnya, atasan atau pemegang kuasa anggaran menerima informasi yang belum diketahui sebelumnya dan meningkatkan akurasi pemahaman terhadap bawahan atau pelaksana anggaran (Suartana, 2010).

\section{Penelitian Terdahulu}

Gamal (2001) meneliti tentang pengaruh interaksi partisipasi anggaran, informasi asimetris dan penekanan anggaran terhadap budget slack (Studi kasus pada Samudra Indonesia Group). Dari Hasil penelitian menunjukkan interaksi ketiga variabel partisipasi, informasi asimetris dan penekanan anggaran secara signifikan mempunyai hubungan dengan slack anggaran. Hubungan ini bermakna semakin tinggi interaksi antara partisipasi informasi asimetris dan penekanan pada anggaran maka upaya membangun slack anggaran akan semakin rendah. Sebaliknya semakin rendah interaksi antara 
Lukman Effendy: Asimetri Informasi dan Budgetary Slack...

partisipasi, informasi asimetris dan penekanan pada anggaran maka upaya membangun slack anggaran semakin tinggi.

Falikhatun (2007) meneliti tentang Interaksi Informasi Asimetri, budaya organisasi dan Group Cohesiveness dalam Hubungan antara partisipasi penganggaran dan budgetary slack (Studi Kasus pada RSUD Se Jawa Tengah). Hasil penelitian menunjukkan Hasil penelitian menunjukkan bahwa partisipasi penganggaran berpengaruh terhadap budgetary slack, sehingga perlu dilakukan pengendalian internal yang lebih memadai dalam pelaksanaan anggaran di Rumah Sakit Umum daerah dan Variabel informasi asimetri dan group cohesiveness merupakan variabel yang dapat memperkuat pengaruh partisipasi penganggaran terhadap budgetary slack, sehingga perlu peningkatan komitmen dalam pelaksanaan program Rumah Sakit terutama yang terkait dengan peningkatan kesejahteraan karyawan.

\section{Kerangka Konseptual}

Berdasarkan hasil penelitian terdahulu dan landasan teori yang telah diuraikan, dapat digambarkan rerangka konseptual penelitian sebagai berikut: Gambar1. Kerangka Konseptual Penelitian

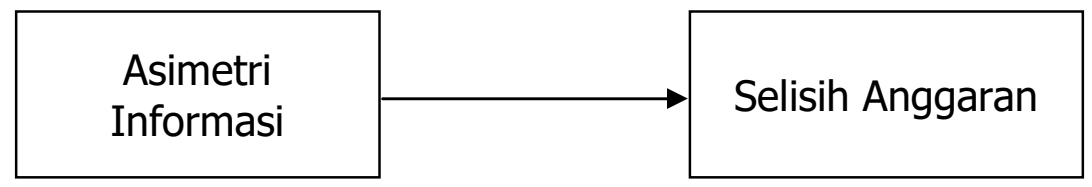

\section{Pengembangan Hipotesis}

Hubungan keagenan antara manajer atas dengan manajer bawah tidak jarang sering menimbulkan masalah mengenai kesenjangan informasi, dimana manajer atas kurang memiliki informasi terkait unit ataupun pusat tanggung jawab yang dikelola oleh manajer bawah. Kesenjangan informasi inilah yang kemudian disebut asimetri informasi. Kebutuhan anggaran sengaja dilonggarkan dari estimasi terbaik sesungguhnya dengan tujuan para manajer bawah dapat mencapai target anggaran dengan mudah. Karena motif kepentingan pribadi, manajer bawah sengaja melakukan senjangan anggaran untuk penilaian kinerja yang baik dari manajemen. Seiring peningkatan kinerja, maka insentif yang diberikan pun akan semakin meningkat.

Gamal (2001) dan Falikhatun (2007) membuktikan bahwa adanya pengaruh asimetri informasi terhadap selisih anggaran. Falikhatun (2007) membuktikan bahwa asimetri informasi membawa pengaruh negatif, yang berarti bahwa meningkatnya asimetri informasi akan menurunkan budgetary slack. 
Dari uraian di atas dapat dirumuskan hipotesis yaitu asimetri informasi berpengaruh terhadap budgetary slack.

\section{METODOLOGI PENELITIAN}

\section{Jenis Penelitian}

Jenis penelitian ini adalah jenis penelitian asosiatif. Penelitian asosiatif/hubungan merupakan penelitian yang bertujuan untuk mengetahui hubungan dua variabel atau lebih. Penelitian ini merupakan tingkat yang tertinggi dibandingkan dengan penelitian deskriptif maupun komparatif. Pada penelitian ini, maka akan dapat dibangun suatu teori yang dapat berfungsi untuk menjelaskan, meramalkan, dan mengontrol suatu gejala (Sugiyono, 2011:11). Hubungan antara variabel ada 3 bentuk, yaitu: simetris, kausal, dan interaktif. Hubungan yang digunakan dalam penelitian ini adalah hubungan kausal, yaitu hubungan yang terjadi karena sebab akibat (Sugiyono, 2011:12).

\section{Lokasi Penelitian}

Penelitian ini dilakukan pada Pemerintah Daerah Kabupaten Dompu. Alasan yang menjadi pertimbangan peneliti untuk mengambil lokasi penelitian adalah atas dasar kemudahan memperoleh data dalam melaksanakan penelitian.

\section{Populasi dan Sampel Penelitian}

Populasi adalah wilayah generalisasi yang terdiri atas obyek atau subjek yang mempunyai kuantitas dan karasteristk tertentu yang ditetapkan oleh peneliti untuk dipelajari dan ditarik kesimpulan (Sugiyono, 2011). Dalam Penelitian ini, populasi adalah seluruh pejabat struktural Satuan Kerja Perangkat Daerah (SKPD)/instansi pemerintah yang ada pada Kabupaten Dompu sebanyak 538 orang yang tersebar pada 37 SKPD (Badan/Dinas/Kantor/Camat). Pengambilan sampel mengunakan pendekatan Tabachnick dan Fidel (2007). Rumus yang digunakan untuk menghitung sampel yang dibutuhkan, berkaitan dengan variabel bebas yang digunakan menurut Tabachnick dan Fidel (2007). Sehingga sampel adalah berjumlah 74 responden.

Sampel adalah bagian dari jumlah dan karasteristik yang dimiliki oleh populasi tersebut (Sugiyono, 2013). Metode sampel yang digunakan adalah metode sampel non probabilitas (Non Probability sampling) yaitu porposive sampling. Porposive sampling digunakan karena informasi yang akan diambil berasal dari sumber yang sengaja dipilih berdasarkan kriteria yang ditetapkan 
Lukman Effendy: Asimetri Informasi dan Budgetary Slack...

peneliti. Sampel terpilih sebanyak 3 responden dari 29 SKPD dan 2 responden dari 8 Kecamatan sehingga total berjumlah 37 dinas/instansi. Responden dalam penelitian ini adalah pejabat struktural yakni Eselon II (Sekretaris Daerah/Kepala Dinas/Kepala Inspentorat/Kepala Badan), Eselon III ( Sekretaris Bidang Dinas/Inspektorat/Badan,Camat), Eselon IV (Kepala Sub.Bagian/Kepala Seksi).

Jumlah responden 100 untuk 37 dinas/instansi ( Eselon II, Eselon III, Eselon IV) (Lampiran 2). Sampel terpilih sebanyak 100 responden untuk 37 dinas/instansi di Pemerintah Kabupaten Dompu, sudah melebihi jumlah minimum yang disarankan oleh Tabachinick dan Fidel (2007) yakni $\mathrm{n}$ (sampel) $>74$ atau $100>74$.

\section{Variabel Penelitian \\ Klasifikasi Variabel}

1. Variabel Eksogen, yaitu variabel yang mempengaruhi atau yang menjadi sebab perubahannya atau timbulnya variabel terikat (Sugiyono, 2014:59). Dalam penelitian ini variabel eksogen adalah Asimetri Informasi.

2. Variabel Endogen, yaitu variabel yang dipengaruhi atau yang menjadi akibat, karena adanya variabel bebas (Sugiyono, 2014:59). Dalam penelitian ini variabel endogen adalah Budgetary Slack.

\section{Definisi Operasional Variabel}

Variabel-variabel penelitian dapat didefinisikan sebagai berikut :

1. Budgetary Slack (Y)

Menurut Govindarajan dan Anthony (2007) Senjangan anggaran adalah perbedaan antara anggaran yang dinyatakan dan estimasi anggaran terbaik yang secara jujur dapat diprediksi serta dibuat oleh penyusun anggaran dalam penganggaran. Instrumen yang digunakan berupa kuesioner yang dikembangkan oleh Sandrya (2015) di organisasi sektor publik. Indikator Senjangan anggaran $(\mathrm{Y}$ ) adalah (a) jumlah anggaran pendapatan yang dibuat lebih rendah dari seharusnya dan (b) jumlah anggaran belanja yang dibuat lebih tinggi dari seharusnya. Variabel diukur dengan 5 item pernyataan, setiap item pertanyaan diukur dengan menggunankan skala Likert 1 sampai 5 poin. Jawaban senjangan anggaran yang rendah untuk skala rendah dan sebaliknya senjangan anggaran lebih tinggi untuk jawaban pada skala tinggi.

2. Asimetri Informasi $(X)$

Asimetri Informasi menunjukkan perbedaan informasi yang dimiliki atasan dan bawahan dalam suatu organisasi. Asimetri informasi merupakan salah satu faktor penyebab terjadinya senjangan anggaran (budgetary slack). 
Kesempatan berpartisipasi digunakan agen untuk membuat senjangan anggaran (budgetary slack) guna meningkatkan kinerjanya.

Instrumen penelitian berupa kuesioner yang dikembangkan oleh Novia (2015), Indikator asimetri informasi $X$ diukur dengan 4 indikator, yaitu: (a) Kecukupan informasi, (b) Kualitas informasi dan (c) Kuantitas Informasi dan (d) Pemahaman informasi. Variabel Asimetri Informasi terdiri dari 6 item pernyataan. Setiap item pertanyaan yang dijawab dengan menggunakan metode pengukuran skala likert 1 sampai 5 . Skala rendah menunjukkan informasi asimetri yang rendah, dan skala tinggi menunjukkan informasi asimetri yang tinggi.

Mengingat bahwa hasil penelitian ini dipastikan nilai skor rata-rata pada masing-masing variabel diatas yang bersumber dari pernyataan atau persepsi 100 responden tidak bulat, maka untuk menentukan nilai kriteria dan kategori dalam penelitian ini dilakukan penilaian dengan menggunakan interval kelas dengan rumus sebagai berikut :

Interval Kelas $=\frac{\text { Nilai tertinggi }- \text { nilai terendah }}{\text { JumlahKelas }}$

Nilai skor tertinggi dalam penelitian ini adalah 5 dan nilai terendah adalah 1 yang berasal dari skala penilaian kuesioner, dan jumlah kelas adalah 5 . Dengan demikian didapatkan :

Interval Kelas $=\frac{5-1}{5}=0,8$

Tabel 2. Rentang Kriteria dan Kategori Sebagai Panduan Pengelompokan Hasil Penilaian

\begin{tabular}{|c|c|c|c|}
\hline \multirow[t]{2}{*}{ No } & \multirow{2}{*}{$\begin{array}{l}\text { Interval } \\
\text { Kriteria }\end{array}$} & \multicolumn{2}{|c|}{ Kategori Variabel } \\
\hline & & $\begin{array}{l}\text { Senjangan } \\
\text { Anggaran }\end{array}$ & $\begin{array}{l}\text { Asimetri } \\
\text { Informasi }\end{array}$ \\
\hline 1. & $4,2 \mathrm{~s} / \mathrm{d} 5$ & Sangat Tinggi & Sangat Tinggi \\
\hline 2. & $\begin{array}{l}3,4 \mathrm{~s} / \mathrm{d}< \\
4,2\end{array}$ & Tinggi & Tinggi \\
\hline 3. & $\begin{array}{l}2,6 \mathrm{~s} / \mathrm{d}< \\
3,4\end{array}$ & Cukup Tinggi & Cukup Tinggi \\
\hline 4. & $\begin{array}{l}1,8 \mathrm{~s} / \mathrm{d}< \\
2,6\end{array}$ & Kurang Tinggi & Kurang Tinggi \\
\hline 5. & $1 \mathrm{~s} / \mathrm{d}<1,8$ & Tidak Tinggi & Tidak Tinggi \\
\hline
\end{tabular}

\section{Prosedur Pengumpulan Data}

Data merupakan terpenting dalam penelitian dimana hakikat dari penelitian adalah pencarian data nantinya diinterpretasikan dan dianalisis serta sangat diperlukan untuk mendukung dan membuktikan mengenai 
Lukman Effendy: Asimetri Informasi dan Budgetary Slack...

hipotesis yang diajukan. Adapun pengumpulan data dalam penelitian ini dilakukan beberapa tahap sebagai berikut :

1. Studi Kepustakaan

Studi kepustakaan merupakan langkah yang penting dimana setelah seorang peneliti menetapkan topik penelitian, langkah selanjutnya adalah melakukan kajian yang berkaitan dengan teori yang berkaitan dengan topik penelitian. Dalam pencarian teori, peneliti akan mengumpulkan informasi sebanyak-banyaknya dari kepustakaan yang berhubungan. Sumber-sumber kepustakaan dapat diperoleh dari : buku, jurnal, majalah, hasil-hasil penelitian (tesis dan disertasi), dan sumber-sumber lainnya yang sesuai. (Nazir, 1998)

2. Studi Lapangan

Studi lapangan pada hakekatnya merupakan metode menemukan secara spesifik dan realis tentang apa yang sedang terjadi pada suatu pada saat ditengah-tengah masyarakat. (Mardalis, 1993;28). Terdapata bebarapa metode studi lapangan, yakni :

a. Observasi

Arikunto (2010:199) meliputi kegiatan pemuatan perhatian terhadap sesuatu objek dengan menggunakan seluruh alat indra. Teknik ini dilakukan dengan cara mengamati dan mencatat secara teliti. Dalam penelitian ini observasi yang digunakan bersifat kuantitatif yakni dengan mencatat jumlah peristiwa-peristiwa penting tingkah laku tertentu.

b. Angket

Arikunto (2003:140) angket atau kuesioner merupakan sejumlah pertanyaan tertulis yang digunakan untuk memperoleh informasi dari responden dalam arti laporan tentang pribadinya, atau hal yang responden ketahui, sedangkan menurut Sugiyono (2009:199) angket adalah teknik pengumpulan data yang dilakukan dengan cara memberi seperangkat pertanyaan atau pernyataan tertulis kepada responden untuk dijawabnya.

\section{Prosedur Analisia Data}

Data dalam penelitian ini adalah data primer. Data primer merupakan data yang diperoleh langsung dari sumber asli. Data primer mengacu pada informasi yang diperoleh dari tangan pertama oleh peneliti yang berkaitan dengan variabel minat untuk tujuan spesifik studi (Sekaran, 2006:60). Data primer yang diperoleh dari hasil pengisian kuesioner oleh responden. Kuesioner akan dibagikan ke Pegawai Negeri Sipil/aparat pemerintah yang menjadi responden, yang terdiri dari Kepala SKPD 
(Dinas/Badan/Kantor/Camat) selaku Penanggungjawab penyusunan anggaran; Sekretaris Dinas/ Badan/ Sekretaris Camat selaku koordinator dalam penyusunan anggaran; dan Kasubbag. Program/Perencanaan/Kasubbag Tata Usaha selaku penyusun anggaran berjumlah 100 kuisioner.

\section{Analisis Statistik Deskriptif}

Menurut Sugiyono (2013:147), statistik deskriptif adalah statistik yang digunakan untuk menganalisis data dengan cara mendeskripsikan atau menggambarkan data yang telah terkumpul sebagaimana adanya tanpa bermaksud membuat kesimpulan yang berlaku untuk umum atau generalisasi. Termasuk dalam statistik deskriptif antara lain adalah penyajian data melalui tabel, grafik, diagram lingkaran, pictocram, perhitungan modus, median, mean (pengukuran tendensi sentral), perhitungan desil, persentil, perhitungan penyebaran data melalui perhitungan rata-rata dan standar deviasi, perhitungan prosentase. Dalam statistik deskriptif tidak ada uji signifikansi, tidak ada taraf kesalahan, karena peneliti tidak bermaksud membuat generalisasi, sehingga tidak ada kesalahan generalisasi (Sugiyono, 2013:148).

Selanjutnya menurut Ghozali (2013:19), statistik deskriptif memberikan gambaran atau deskripsi tentang suatu data yang dilihat melalui nilai ratarata (mean), standar deviasi, varian, maksimum, minimum, sum, range, kurtosis, dan skewness (kemencengan distribusi). Skewness dan kurtosis merupakan ukuran untuk melihat apakah data terdistribusi secara normal atau tidak. Skewness mengukur kemencengan dari data dan kurtois mengukur puncak dari distribusi data. Data yang terdistribusi secara normal mempunyai nilai skewness dan kurtois mendekati nol (Ghozali, 2013:21).

\section{Analisis Data}

Analisis data dalam penelitian ini menggunakan pendekatan Partial Least Square (PLS) menggunakan software SmartPLS versi 2.0 M3. Partial Least Square merupakan metode analisis yang powerfull dan sering disebut sebagai soft modeling karena meniadakan asumsi-asumsi OLS (Ordinary Least Squares) regresi, seperti data harus terdistribusi normal secara multivariate dan tidak adanya problem multikolonieritas antar variabel eksogen (Wold 1985 dalam Latan dan Ghozali, 2012:6).

Tahapan analisis menggunakan PLS-SEM setidaknya harus melalui lima proses tahapan dimana setiap tahapan akan berpengaruh terhadap tahapan selanjutnya, yaitu (1) konseptualisasi model, (2) menentukan metoda analisis 
Lukman Effendy: Asimetri Informasi dan Budgetary Slack...

algorithm, (3) menentukan metoda resampling, (4) menggambar diagram jalur, dan (5) evalusi model (Latan dan Ghozali, 2012:6)

\section{Evaluasi Model}

Tahapan evaluasi model terdiri atas evaluasi outer model dan evaluasi inner model. Evaluasi outer model dilakukan untuk menilai validitas dan reliabilitas model, sedangkan evaluasi inner model dilakukan untuk memprediksi hubungan antar variable laten (Latan dan Ghozali, 2012:77). Tahapan yang dilakukan meliputi:

1. Evaluasi Outer Model.

Uji yang dilakukan untuk outer model dengan indikator reflektif antara lain:

a. Convergent validity, merupakan uji validitas konvergen yang dapat dilihat dari nilai loading factor untuk tiap indikator konstruk. Rentang nilai loading factor yaitu 0,50 sampai 0,60 dianggap cukup (Chin, 1998 dalam Ghozali, 2008:24).

b. Discriminant validity, merupakan cara untuk menguji validitas diskriminan dengan indikator reflektif yaitu dengan melihat nilai korelasi cross loading. Nilai korelasi cross loading harus lebih besar dibandingkan dengan korelasi terhadap variabel laten yang lain yaitu $>0,70$.

c. Composite Reliability. Nilai composite reliability lebih besar dari 0,7 menunjukan bahwa data mempunyai nilai reliability tinggi (Latan dan Ghozali, 2012:81).

2. Pengujian Inner Model berfungsi untuk menguji hubungan antara konstruk laten (pengujian hipotesis) antara lain:

a. R Square pada konstruk endogen digunakan untuk melihat kemampuan variabel eksogen untuk menerangkan variabel endogen. Klasifikasi Nilai R square menurut Chin (1998) dalam Latan dan Ghozali (2012:85) terdiri dari 0,67 (kuat), 0,33 (moderate) dan 0,19 (lemah).

b. Predictive relevance ( $Q$ square) digunakan untuk mengetahui kapabilitas prediksi dengan prosedur blinfolding.

3. Pengujian Hipotesis dilakukan dengan membandingkan nilai T-table dengan nilai T-statistic yang dihasilkan dari proses bootstrapping dalam PLS. Hipotesis diterima (terdukung) jika nilai T-statistic lebih tinggi daripada nilai T-table $(1,65)$ dengan signifikansi level $10 \%$ (two tailed) (Latan dan Ghozali, 2012:85). 


\section{HASIL PENELITIAN DAN PEMBAHASAN}

\section{Gambaran Umum Pemerintah Daerah Kabupaten Dompu}

Kabupaten Dompu merupakan salah satu kabupaten yang berada di wilayah provinsi Nusa Tenggara Barat (NTB) yang terletak di pulau Sumbawa. Secara administrasi wilayah kabupaten Dompu terdiri atas 8 (delapan) kecamatan, dengan luas wilayah 232.455 Ha daratan dan 239.296 Ha perairan.

Kabupaten Dompu dalam penyelenggaraan pemerintahan, memiliki 37 (tiga puluh tujuh) SKPD (Satuan Kerja Perangkat Daerah), terdiri dari: 1 Sekretariat Daerah, 1 Sekretariat Dewan, 1 RSUD, 1 Inspektorat, 14 Dinas, 7 Badan, dan 12 Kantor. Pelaksanaan pengelolaan keuangan daerah dalam perencanaan dan penganggaran mengacu pada Undang-Undang Nomor 25 Tahun 2004 tentang Sistem Perencanaan Pembangunan Nasional memuat perubahan-perubahan mendasar dalam perencanaan dan penyusunan anggaran, yang salah satunya adalah pendekatan anggaran berbasis kinerja. Proses penganggaran di daerah menggunakan pendekatan kinerja diatur dalam Permendagri Nomor 21 Tahun 2011 tentang Perubahan kedua atas Permendagri Nomor 13 Tahun 2006 tentang Pedoman Pengelolaan Keuangan Daerah, menjelaskan tentang pedoman dalam pembentukan rancangan anggaran pendapatan dan belanja daerah (RAPBD), pembentukan RAPBD dilaksanakan oleh Tim Anggaran Pemerintah Daerah (TAPD) bersama-sama unit organisasi perangkat daerah (unit kerja).

\section{Karakteristik Responden}

Pemilihan responden pada penelitian ini didasarkan pada pertimbangan bahwa responden adalah aparat/pejabat teknis yang terlibat dalam penyusunan anggaran di setiap SKPD. Responden dalam penelitian ini adalah Kepala SKPD, Sekretaris Dinas/ Badan/ Sekretaris Camat, dan Kasubbag. Program/ Perencanaan/ Kasubbag Tata Usaha di lingkup Pemerintah Daerah Kabupaten Dompu merupakan pejabat/aparat yang bertanggung jawab dan terlibat langsung dalam proses penyusunan anggaran.

\section{Karakteristik Responden Berdasarkan Umur}

Umur responden menggambarkan tingkat kedewasaan, sehingga dapat mempengaruhi partisipasi dalam proses penganggaran daerah Kabupaten Dompu. Sebagian besar responden berumur $>50$ tahun sebanyak 33 orang (36,7 persen), diharapkan responden sudah lebih objektif dalam menjawab pertanyaan dalam kuisioner. 
Lukman Effendy: Asimetri Informasi dan Budgetary Slack...

\section{Karakteristik Responden Berdasarkan Jenis Kelamin}

Jenis kelamin responden digunakan untuk mengetahui keterlibatan gender dalam proses penganggaran di Kabupaten Dompu. Hasil penelitian menunjukkan bahwa sebagian besar responen berjenis kelamin pria sebanyak 68 orang ( 75,6 persen) dan wanita sebanyak 22 orang (24,6 persen) dari jumlah total responden sebanyak 90 orang.

\section{Karakteristik Responden Berdasarkan Tingkat Pendidikan}

Secara umum tingkat pendidikan seseorang dapat mempengaruhi sikap, pengambilan keputusan serta kemampuan dalam menyelesaikan suatu pekerjaan secara lebih efektif dan efisien sehingga tingkat pendidikan responden digunakan sebagai indikator untuk mengetahui tingkat intelektualitas responden yang berpartisipasi dalam proses penganggaran (APBD) di Kabupaten Dompu.

Hasil penelitian menunjukkan bahwa tingkat pendidikan responden lebih banyak berpendidikan S1 sebanyak 58 orang atau sebesar 64,4 persen dari jumlah total responden sebanyak 90 orang, artinya bahwa SDM yang menempati jabatan tertentu lebih banyak dengan tingkat pendidikan S1.

\section{Karakteristik Responden Berdasarkan Lama Bekerja}

Lama bekerja erat hubungannya dengan pengalaman kerja, kepercayaan diri dan pemahaman tentang pekerjaan yang lebih baik. Hasil penelitian menunjukkan bahwa lama bekerja responden mayoritas $21 \mathrm{~s} / \mathrm{d} 25$ tahun sebanyak 25 orang atau sebesar 24,4 persen dari jumlah total responden sebanyak 90 orang. Artinya bahwa sebagian besar sumber daya manusia yang menempati jabatan tertentu memiliki pengalaman kerja.

\section{Statistik Deskriptif}

\section{Deskriptif Variabel Budgetary Slack}

Skor rata-rata untuk masing-masing indikator dari variabel Senjangan anggaran pada kisaran diatas 2,63. Skor tersebut memperlihatkan bahwa senjangan anggaran pada Pemerintah Daerah Kabupaten Dompu, menunjukkan nilai yang cukup tinggi, artinya bahwa semua indikator dari variabel senjangan anggaran, berdasarkan kuesioner menunjukkan nilai di atas rata-rata. Hal ini juga mengindikasikan adanya senjangan anggaran pada Pemerintah Daerah Kabupaten Dompu. Tabel 3 menunjukkan nilai skor ratarata indikator pada Variabel Senjangan Anggaran 
Tabel 3

Nilai Skor Rata-rata Indikator pada Variabel Senjangan Anggaran

\begin{tabular}{|l|l|c|c|}
\hline No & \multicolumn{1}{|c|}{ Indikator Variabel } & $\begin{array}{c}\text { Kode } \\
\text { Indikator }\end{array}$ & Rata -Rata \\
\hline 1 & $\begin{array}{l}\text { Jumlah anggaran pendapatan } \\
\text { yang dibuat lebih rendah dari } \\
\text { seharusnya. }\end{array}$ & $\mathrm{Y} 1$ & 2,46 \\
\hline 2 & $\begin{array}{l}\text { Jumlah anggaran belanja yang } \\
\text { dibuat lebih tinggi dari seharusnya }\end{array}$ & $\mathrm{Y} 2$ & 2,81 \\
\hline$\quad$ Rata - Rata Skor & \multicolumn{2}{|c|}{2,62} \\
\hline
\end{tabular}

Sumber: Data Primer diolah

\section{Deskriptif Variabel Asimetri Informasi}

Skor atau jawaban responden terhadap kuesioner variabel Asimetri Informasi merupakan persepsi responden terhadap perbedaan informasi yang dimiliki atasan dan bawahan dalam suatu organisasi. Cara memperoleh dan menggunakan informasi yang berkaitan dengan pekerjaan yang dilakukan berdasarkan kondisi yang dialami pada saat bekerja di instansi/SKPD masingmasing reponden. Skor rata-rata untuk masing-masing indikator dari variabel Asimetri Informasi pada kisaran diatas 3,65. Skor tersebut memperlihatkan bahwa para aparat atau pejabat struktural pada masing-masing SKPD Pemerintah Daerah Kabupaten Dompu cenderung memiliki, mengumpulkan dan menggunakan perbedaan informasi yang berkenaan dengan pekerjaan dalam bekerja pada instansinya, skor tersebut tinggi sehingga berpengaruh pada partisipasi anggaran terhadap senjangan anggaran. Tabel 4 menunjukkan nilai skor rata-rata indikator pada Variabel Asimtetri Informasi.

Tabel 4.

Nilai Skor Rata-rata Indikator pada Variabel Asimetri Informasi

\begin{tabular}{|c|l|c|c|}
\hline No & \multicolumn{1}{|c|}{ Indikator Variabel } & $\begin{array}{c}\text { Kode } \\
\text { Indikator }\end{array}$ & Rata -Rata \\
\hline 1 & Kecukupan informasi & $\mathrm{X} 1$ & 3,47 \\
\hline 2 & Kualitas informasi & $\mathrm{X} 2$ & 4,02 \\
\hline 3 & Kuantitas informasi & $\mathrm{X} 3$ & 3,56 \\
\hline 4 & Pemahaman informasi & $\mathrm{X} 4$ & 3,54 \\
\hline \multicolumn{3}{|c|}{ Rata - Rata Skor } & 3,65 \\
\hline
\end{tabular}

Sumber: Data Primer diolah 
Lukman Effendy: Asimetri Informasi dan Budgetary Slack...

\section{Statistik Inferensial}

Statistik inferensial, (sering juga disebut statistik induktif atau statistik probabilitas), adalah teknik statistik yang digunakan untuk menganalisis data sampel dan hasilnya diberlakukan untuk populasi (Sugiyono, 2014:207). Analisis data pada penelitian ini menggunakan Structural Equation Modelling (SEM) berbasis varian atau biasa disebut dengan soft modeling, dengan menggunakan alat analisis Partial Least Square (PLS). Alat bantu atau software yang digunakan untuk memprediksi pengaruh variabel laten dalam penelitian ini berupa Smart PLS Versi 3.2.1.

\section{Pengujian Model Pengukuran (Outer Model)}

Model pengukuran digunakan untuk menguji validitas konstruk dan reliabilitas instrumen. Uji validitas dalam penelitian ini yaitu convergent validity dan discriminant validity, sedangkan untuk uji reliabilitas yaitu composite reliability. Proses pengujian model pengukuran (Outer Model) melalui pengujian validitas dan reliablitas indikator terhadap konstruk dilakukan melalui langkah-langkah sebagai berikut :

\section{Pengujian Convergent Validity}

Convergent validity dari model pengukuran dengan refleksif indicator dinilai berdasarkan korelasi antara item score/component score dengan construct score yang dihitung dengan PLS (Ghozali, 2008:24). Hal senada juga disampaikan oleh Jogiyanto (2011:71) uji validitas konvergen dalam PLS dengan indikator reflektif dinilai berdasarkan loading factor (korelasi antara skor item/skor komponen dengan skor konstruk) indikator-indikator yang mengukur konstruk tersebut. Menurut Chin (1995) dalam Jogiyanto, (2011:71) rule of thumb yang digunakan untuk validitas konvergen adalah outer loading $>0,7$. Communality $>0,5$ dan Average Variance Extracted $($ AVE $)>0,5$. Hasil analisis dapat dilihat pada gambar berikut ini:

Gambar 2. Hasil Uji Convergent Validity

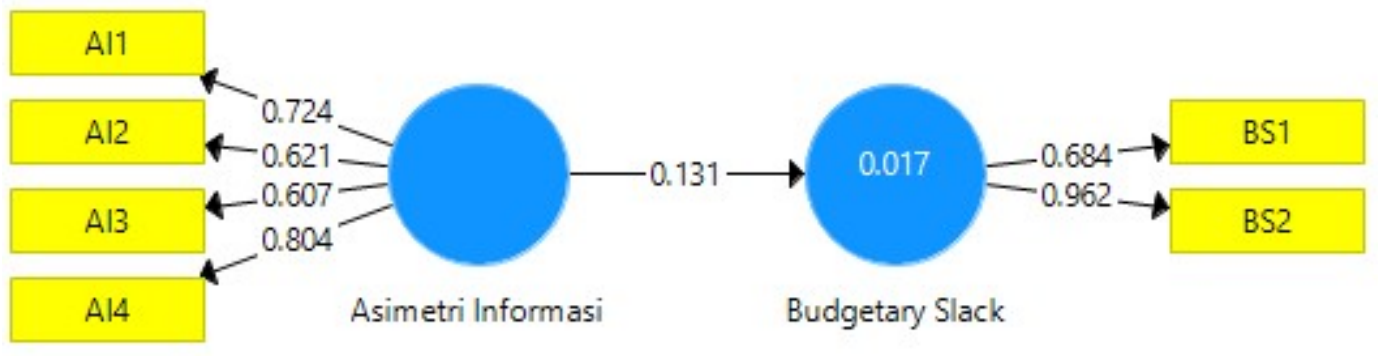

Berdasarkan hasil analisis, tidak terdapat variabel manifes/teramati/indikator yang memiliki nilai loading factor $<0,50$, maka indikator-indikator tersebut tidak didrop dari model. 


\section{Pengujian Discriminant Validity}

Discriminant validity dari model pengukuran dengan refleksif indikator dinilai berdasarkan cross loading pengukuran dengan konstruknya. Metode lain untuk menilai discriminant validity adalah membandingkan nilai square root of average variance extrated (AVE) setiap konstruk dengan korelasi antara konstruk dengan konstruk lainnya dalam model. Dalam penelitian ini metode yang dipakai adalah dengan melihat nilai cross loading. Nilai cross loading dapat dilihat table berikut:

Tabel 5. Hasil Uji Discriminant Validity

\begin{tabular}{|l|c|c|}
\hline & Asimetri Informasi & Budgetary Slack \\
\hline AI1 & $\mathbf{0 , 7 2 4}$ & 0,079 \\
\hline AI2 & $\mathbf{0 , 6 2 1}$ & 0,079 \\
\hline AI3 & $\mathbf{0 , 6 0 7}$ & 0,077 \\
\hline AI4 & $\mathbf{0 , 8 0 4}$ & 0,120 \\
\hline BS1 & 0,053 & $\mathbf{0 , 6 8 4}$ \\
\hline BS2 & 0,140 & $\mathbf{0 , 9 6 2}$ \\
\hline
\end{tabular}

Sumber: Data primer diolah

Berdasarkan nilai cross loading untuk semua konstruk $>0,60$, sehingga memenuhi persyaratan discriminant validity.

\section{Pengujian Composite Reliability}

Uji reliabiltas pada model pengukuran (outer model) pada indikator reflektif dengan melihat nilai Composite Reliability. Indikator dinyatakan reliabel atau memiliki reliabilitas baik apabila nilai Composite Reliability > 0,70 . Hasil perhitungan Composite Reliability dalam penelitian ini, dapat dilihat pada tabel berikut :

Tabel 6. Nilai Composite Reliability

\begin{tabular}{|c|c|}
\hline & Composite Reliability \\
\hline Asimetri Informasi & 0,785 \\
\hline Budgetary Slack & 0,817 \\
\hline
\end{tabular}

Sumber: Data primer diolah

Tabel di atas menunjukkan bahwa nilai composite reliability $>0,70$, sehingga dapat disimpulkan bahwa semua indikator konstruk adalah reliabel atau memenuhi uji reliabilitas.

\section{Persamaan Model Pengukuran (Outer Mode)}

Proses uji validitas dan uji reliabilitas telah menghasilkan model pengukuran dengan indikator yang telah valid dan reliabel. Setelah dilakukan 
Lukman Effendy: Asimetri Informasi dan Budgetary Slack...

uji validitas dan reliabilitas konstruk maka persamaan model pengukuran (outer mode) yang memenuhi syarat convergent validity, discriminant validity dan composite reliability dalam penelitian ini sebagaimana ditunjukkan pada Tabel sebagai berikut :

Tabel 7. Model Pengukuran (Outer Model) yang Terbentuk

\begin{tabular}{|c|l|c|}
\hline No & Variabel & $\begin{array}{c}\text { Model Pengukuran (Outer } \\
\text { Model) }\end{array}$ \\
\hline \multirow{2}{*}{1} & Asimetri Informasi (AI) & AI1 $=0.724+\delta 1$ \\
\cline { 3 - 3 } & & AI2 $=0.621+\delta 2$ \\
\cline { 3 - 3 } & & AI3 $=0.607+\delta 3$ \\
\cline { 3 - 3 } 2 & Budgetary Slack (BS) & AI4 $=0.804+\delta 3$ \\
\cline { 3 - 3 } & & BS1 $=0.684+\varepsilon 3$ \\
\hline
\end{tabular}

Sumber: Data primer diolah

\section{Model Struktural (Inner Model) \\ Evaluasi $\boldsymbol{R}$-square}

Evaluasi inner model dilakukan dengan uji bootstrapping. Evaluasi model struktural (inner model) merupakan model struktural untuk memprediksi hubungan kausalitas antar variabel laten melalui uji bootstrapping, untuk memprediksi adanya hubungan kausalitas model structural (inner model) dievaluasi dengan menggunakan $R$-square untuk konstruk dependen, Stone-Geiser Q-square test untuk predictive relevance dan uji t serta signifikansi dari koefisien parameter jalur struktural. Dalam menilai model dengan PLS dengan melihat $R$-square untuk setiap variabel laten eksogen. Hasil evaluasi inner mode/ dijelaskan sebagai berikut, untuk Tabel dibawah ini menunjukkan nilai $R$-square.

Tabel 8. Nilai $R$-square
\begin{tabular}{|c|c|}
\hline Kinerja Keuangan $\quad 0,017$ \\
\hline
\end{tabular}

Hasil analisis pada Tabel di atas menunjukkan nilai $R$-square untuk variabel laten endogen Kinerja Keuangan adalah 0,017 yang berarti model ini mampu menjelaskan 1,70 persen perubahan pada variabel laten endogen Kinerja Keuangan dan sisanya sebesar 98,30 persen dijelaskan oleh faktor lain diluar yang diteliti.

\section{Evaluasi Predictive relevance ( $Q$ square)}

Selain dengan menggunakan metode diatas, metode lain untuk melihat model PLS juga dievaluasi dengan melihat $Q$-square predictive relevance untuk model konstruk. Q-square mengukur seberapa baik nilai 
observasi dihasilkan oleh model dan juga estimasi parameternya. Suatu model dianggap mempunyai nilai predictive yang relevan jika nilai Q-square lebih besar dari $0(>0)$, sedangkan nilai $Q$-square kurang dari $0(<0)$ menunjukkan bahwa model kurang memiliki predictive relevance. Nilai $Q$ square predictive-relevance diperoleh dengan rumus sebagai berikut :

\section{Perhitungan Q-Square Predictive-Relevance}

Hasil perhitungan $Q$-square predictive-relevance pada penelitian ini adalah

$$
\begin{aligned}
\mathrm{Q}^{2} & =1-\left(1-\mathrm{R}^{2}\right) \\
& =1-(1-0,0170) \\
& =0,0170
\end{aligned}
$$

0,0170. Hal ini berarti model dalam penelitian ini layak untuk menjelaskan variabel endogen yaitu kinerja keuangan.

\section{Pengujian Hipotesis}

Setelah analisis model dilakukan, analisis selanjutnya adalah pengujian hipotesis, analisis ini dilakukan dengan membandingkan nilai $T$ table dengan nilai T-statistics yang dihasilkan dari proses bootstrapping dalam PLS. Hipotesis diterima (terdukung) jika nilai T-statistics lebih tinggi daripada nilai $T$-table $(1,677)$ dengan signifikansi level 10 persen (two tailed) (Ghozali, 2012:85). Hasil proses bootstrapping PLS dapat dilihat pada Tabel 9 dan Gambar 3 sebagai berikut :

Tabel 9. Path Coefficients (Mean, STDEV, T-Values)

\begin{tabular}{|l|c|c|c|c|c|}
\hline & $\begin{array}{c}\text { Origin } \\
\text { al } \\
\text { Sampl } \\
\text { e (O) }\end{array}$ & $\begin{array}{c}\text { Sample } \\
\text { Mean (M) }\end{array}$ & $\begin{array}{c}\text { Standard } \\
\text { Error } \\
\text { (STERR) }\end{array}$ & $\begin{array}{c}\text { T Statistics } \\
\text { (| O/STERR |) }\end{array}$ & P Values \\
\hline $\begin{array}{l}\text { Asimetri } \\
\text { Informasi } \\
=>\end{array}$ & 0.131 & 0.162 & 0.199 & $\mathbf{0 . 6 6 1}$ & $\mathbf{0 . 5 0 9}$ \\
$\begin{array}{l}\text { Budgetary } \\
\text { Slack }\end{array}$ & & & & \\
\hline
\end{tabular}

Sumber: data diolah 
Lukman Effendy : Asimetri Informasi dan Budgetary Slack...

Gambar 3. Hasil Proses Bootstrapping

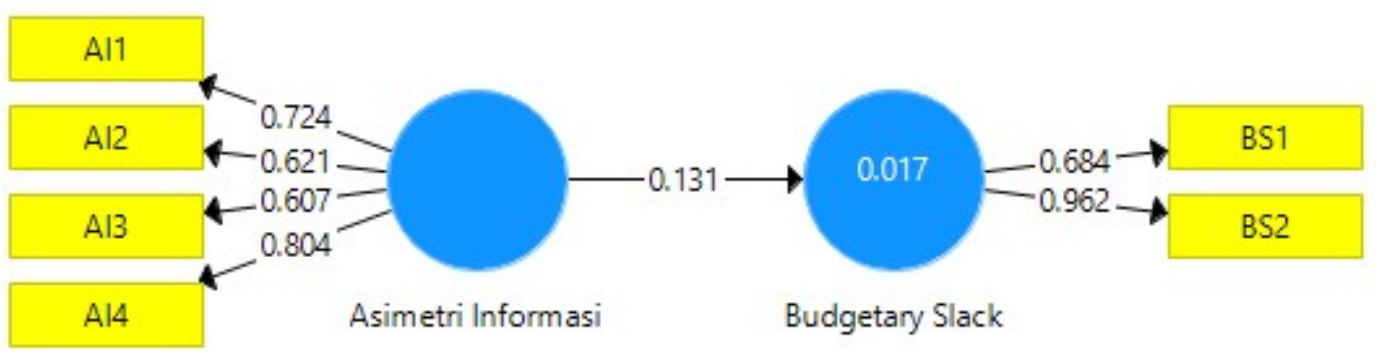

Sumber: Data primer diolah

Berdasarkan tabel dan gambar di atas, dapat diambil kesimpulan bahwa hipotesis yang menyatakan variabel asimetri informasi berpengaruh terhadap budgetary slacktidak terbukti, karena hasil uji hipotesis menunjukkan path coeficient antara partisipasi anggaran dengan senjangan anggaran dengan nilai T-statistics $(0.661)<T$-table $(1,666)$ atau tidak signifikan. Artinya hipotesis tersebut ditolak.

\section{Persamaan Model Struktural (Inner Mode)}

Persamaan model struktural yang diperoleh berdasarkan hasil pengujian inner mode/ dan pengujian hipotesis, sebagai berikut : $\mathrm{BS}=0,017 \mathrm{AI}-\zeta$

Keterangan :

BS = Budgetary Slack

AI = Asimetri Informasi

$\zeta=$ Inner residual variable.

\section{PEMBAHASAN}

\section{Pengaruh Asimetri Informasi Terhadap Budgetary Slack}

Berdasarkan hasil pengujian, menunjukkan bahwa asimetri informasi tidak berpengaruh secara signifikan terhadap budgetary slack. Penelitian ini bertentangan dengan penelitian Gamal (2001) dan Falikhatun (2007). Asimetri informasi yang tidak terbukti bertentangan dengan budgetary slack dimungkinkan karena asimetri informasi yang relatif kecil, karena peraturan meminimalisir hal tersebut. Peraturan yang jelas terkait dengan tugas dan kewajiban pegawai negeri sipil termasuk informasi yang dimiliki oleh bawahan harus dilaporkan kepada atasannya. Peraturan dapat menekan asimetri informasi yang dimiliki oleh bawahan. 


\section{KESIMPULAN DAN SARAN}

Simpulan dari peneltian ini menunjukkan bahwa asimetri informasi tidak berpengaruh secara signifikan terhadap budgetary slack yang diduga karena adanya peraturan-peraturan pemerintahan yang mengatur hak dan kewajiban sebagai pegawai negeri sipil untuk melaporkan informasi yang dimiliki kepada atasannya.

Kecilnya nilai R-Square pada penelitian ini seharusnya dapat ditingkatkan dengan menambahkan variabel-variabel lain seperti partisipasi anggaran, self esteem, komitmen organisasi dan variabel lainnya.

\section{DAFTAR PUSTAKA}

Dunk, Alan S. 1993. The Effect of Budget Emphasis and InformationAsymmetry on the Relation Between Budgetary Participation and Slack. TheAccounting Review, p. 400-410.

Falikhatun, 2007. Interaksi Informasi Asimetri, Budaya Organisasi dan Group Cohensiveness Dalam Hubungan Antara Partisipasi Penganggaran dan Budgetary Slack (Studi Kasus Pada Rumah Sakit Umum Daerah Se-Jawa Tengah). Simposium Nasional Akuntansi (SNA) X, Makasar

Falikhatun, 2007. Pengaruh Partisipasi Penganggaran Terhadap Budgetary Slack dengan Variabel Pemoderasi Ketidakpastian Lingkungan dan Kohesivitas Kelompok.Jurnal Akuntansi dan Keuangan Volume 6, no. 2. Surakarta

Fitri, yulia. 2007. Senjangan Anggaran :Pengaruh Informasi Asimetri, Partisipasi Penganggaran dan Komitmen Organisasi (Studi Empiris pada Universitas Swasta di Kota Bandung). Jurnal Ichsan Gorontalo Volume 2 no. 3. Gorontalo

Gamal Muhammad. 2001. Pengaruh interaksi partisipasi anggaran, informasi asimetris dan penekanan anggaran terhadap budgetslack (Studi kasus pada Samudra Indonesia Group) Tesis. Program Pasca Sarjana. Universitas Diponegoro.

Ghozali Imam. (2011). Aplikasi Analisis Multivariate dengan Program IBM SPSS 19. Edisi 5. Semarang: Badan Penerbit Universitas Diponegoro.

Irfan, Muhammad. 2016. Pengaruh Partisipasi Anggaran Terhadap Senjangan Anggaran Dengan Asimetri Informasi, Penekanan Anggaran, Komitmen Organisasi Sebagai Variabel Moderasi (Studi Pada Skpd Pemerintah Kabupaten Dompu). Tesis. Program Pascasarjana. Universitas Mataram.

Jensen, MC and W. H Meckling, 1976, Theory of The Firm : Managerial Behavior, Agency Cost and Ownership Structure, Journal of Financial Economics, 3, 305-360

Latan, Hengky dan Imam Ghozali.2012. Partial Least Square : Konsep, Teknik dan Aplikasi. Konfrensi Administrasi Negara. Yogyakarta.

Rani Adnyani (2015) Kemampuan Asimetri Informasi, Ketidakpastian Lingkungan, Budget Emphasis, Dan Kapasitas Individu Sebagai Variabel Moderasi 
Lukman Effendy : Asimetri Informasi dan Budgetary Slack...

Terhadap Partisipasi Anggaran Pada Budgetary Slack (Studi Kasus Pada SKPD Di Kabupaten Badung) Tesis. Program Pasca Sarjana. Universitas Udayana

Suartana, I Wayan. 2010. Akuntansi Keperilakuan Teori dan Implementasi. Yogyakarta: C.V Andi Offset.

Sugiyono. (2007). Statistika untuk Penelitian. Yogyakarta: BPFE.

Undang-undang Republik Indonesia No. 32 Tahun 2004 tentang Pemerintah Daerah

Young, S.M. 1985. Participative Budgeting: The Effect of Risk Aversion and Assymetric Information on Budgetary Slack. Journal of Accounting Research, Vol. 23: 829-842 